\title{
A Case of Tracheal Granuloma Removal using Potassium-Titanyl-Phosphate Laser
}

\author{
Ji Song Hong (i) and GilJoon Lee (1) \\ Department of Otorhinolaryngology-Head and Neck Surgery, Chilgok Kyungpook National University Hospital, \\ Kyungpook National University School of Medicine, Daegu, Korea
}

\section{Potassium-Titanyl-Phosphate 레이저를 이용하여 제거한 기관 육아종 1예}

홍지송, 이길준

경북대학교 의과대학 칠곡경북대학교병원 이비인후-두경부외과학교실

Tracheal granuloma, the most commonly reported sequela of pediatric tracheotomy. A variety of techniques are available for the management of tracheal granuloma. Potassium-titanyl-phosphate (KTP) laser has been previously established as an acceptable technique for removal of laryngeal surgery, which emits a green light with a wave length of $532 \mathrm{~nm}$, which is well-absorbed by hemoglobin and can coagulate and vaporize tissue. The ability to deliver laser energy through a flexible glass fiber makes the technique convenient for use with a rigid bronchoscope, overcoming problems with intraluminal access encountered with earlier attempts at $\mathrm{CO}_{2}$ laser therapy for this problem. Another advantage of KTP laser is the avoidance of the risks and morbidity associated with an open procedure. We report our surgical technique KTP laser in the management of tracheal granuloma removal into the tracheostomy site. KTP laser is good tool for management of tracheal granuloma with low incidence of complications.

Keywords Trachea; Granuloma; KTP laser.

\section{서 론}

기관절개술 후 기관 캐뉼라를 장기간 거치하는 경우 캐뉼라가 맞닿는 부위에 지속적 인 자극이 가해지기 때문에 기관 협착이나 기관 내 육아종이 발생할 수 있다. ${ }^{1,2)}$ 특히, 선 천성 기형이나 뇌, 심장, 폐와 같은 주요 기관의 질병을 동반한 소아 환자는 수개월, 수 년 이상 기관 캐뉼라를 유지해야 하는 경우가 많고, 성인에 비해 기관 내면의 면적이 좁 기 때문에 캐뉼라로 인한 기관 협착이나 육아종 발생률이 성인에 비해 높은 것으로 알 려져 있다. ${ }^{3)}$

기관 내 육아종은 호흡곤란이나 천명음 같은 증상을 유발할 수 있으며 보존적 치료에 도 증상이 조절되지 않을 시 수술적 치료를 원칙으로 하며, 기관 내 육아종의 수술적 제 거 방법으로는 개방적 접근법과 내시경적 방법이 있다. 최근 이비인후과 영역에서 내시 경 기술의 발전으로 내시경적 접근법이 활발히 시행되고 있으나 수술 중 출혈이 발생하
Received October 19, 2020

Revised November 9, 2020

Accepted November 27, 2020

\section{Corresponding Author}

GilJoon Lee, MD

Department of Otorhinolaryngology-

Head and Neck Surgery,

Chilgok Kyungpook National

University Hospital,

Kyungpook National University

School of Medicine,

807 Hoguk-ro, Buk-gu,

Daegu 41404, Korea

Tel +82-53-200-2166

Fax+82-53-200-2027

E-mail giljoon.lee@gmail.com

\section{ORCID iDs}

Ji Song Hong (1)

https://orcid.org/0000-0001-8843-8426

GilJoon Lee (D)

https://orcid.org/0000-0002-3344-1879

This is an Open Access article distributed under the terms of the Creative Commons Attribution Non-Commercial License (https://creativecommons.org/ licenses/by-nc/4.0) which permits unrestricted non-commercial use, distribution, and reproduction in any medium, provided the original work is properly cited. 
는 경우 시야 확보가 어려워 지혈하기 쉽지 않으며 지혈을 하 더라도 2차적으로 육아종이나 반흔 형성과 같은 합병증을 야 기할 수 있다. 그러므로 내시경 수술을 진행할 때 술 중 효과 적인 지혈을 위한 적절한 치료 방법을 선정하는 것이 중요하 다. 이러한 출혈성 병변에 대해 레이저(laser)를 사용하는 경 우가 많으며 대표적으로 $\mathrm{CO}_{2}$, potassium-titanyl-phosphate (KTP), neodymium-doped yttrium aluminum garnet(Nd: Yag) 등이 있다. 그 중 $532 \mathrm{~nm} \mathrm{KTP}$ 레이저는 헤모글로빈에 특이적으로 광지혈작용(photocoagulation)을 함으로써 술 중 출혈 위험을 최소화할 수 있으며, 레이저가 굴곡 와이어 형 태로 이루어져 있어 기관 하방에 발생한 병변에도 정확하게 접 근할 수 있는 장점이 있다. ${ }^{4}$ 저자들은 기관절개술 후 발생 한 기관 캐뉼라 하방의 육아종 및 기관 협착으로 인해 호흡 곤란을 주소로 내원한 4세 여아에 대해 KTP 레이저를 이용 하여 육아종을 제거한 증례를 경험하였기에 이를 문헌고찰 과 함께 보고하는 바이다.

\section{증 례}

4세 여자 환아가 호흡곤란 및 천명음을 주소로 내원하였 다. 환아는 재태 연령 40 주, 자연분만으로 출생하였으며 출생 당시 및 주산기에 이상 소견은 없었다. 생후 3개월경 급성 심 근염, 뇌부종으로 인한 저산소성 허혈성뇌병증으로 중환자실 에 입원하였고 생후 3.5 개월경 기관절개술을 시행하였다. 이 후 3년 이상 정기적으로 추적 관찰하며 지내던 중 기관 캐뉼 라 $(5.5 \mathrm{Fr})$ 를 통한 출혈, 천명음을 동반한 호흡곤란 증상으 로 이비인후과 외래로 내원하였다. 굴곡형 후두내시경 검사에 서 기관 분기부(tracheal carina) 상방 $2 \mathrm{~cm}$, 기관 캐뉼라 직하 방 전방측면에 육아종으로 관찰되는 병변이 확인되었고 이로 인해 기관의 부분적인 폐쇄를 유발하는 것으로 생각되었다

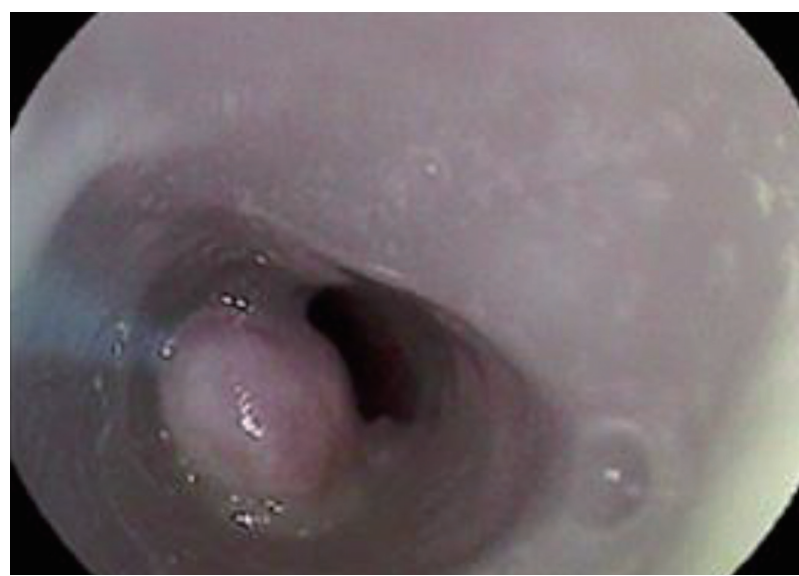

Fig. 1. Flexible laryngoscopic findings. Tracheal granuloma is shown beneath a tracheal cannula tip.
(Fig. 1). 기관 캐뉼라를 발관 후 굴곡형 후두내시경으로 확 인하였을 때 기관 측후벽의 협착 소견도 관찰되었다.

전신마취하에 기관 캐뉼라를 제거한 상태에서 무기하 기 법(apnea technique)하에 30도 내시경 $(4 \mathrm{~mm})$ 으로 육아종 을 확인한 후 미세겸자(micro forcep)를 이용하여 제거하였 다. 이 과정에서 출혈이 발생하였고 흡입형 전기소작기로 지혈 한 후 기관 캐뉼라를 재삽입하고 수술을 종료하였다(Fig. 2). 수술 3주 후 간헐적인 호흡곤란 및 천명음 증상으로 외래 방 문하였고 수술 부위의 육아조직이 다시 확인되었다. 첫 수술 당시 육아종을 제거하는 과정에서 기관 내벽 점막의 손상, 출 혈 시 내시경 시야가 원활하지 않아 전기소작 시 출혈 부위 이 외 조직까지 손상을 주었을 가능성 등을 고려하였고 주변 점 막의 손상 및 출혈 가능성을 최소화하기 위해 KTP 레이저 (Laser 8W, 532 nm; Quanta System, Solbiate Olona, Italy) 를 이용해 수술을 진행하였다. 접근법은 첫 수술과 동일하게 전신마취하 기관 캐뉼라를 제거한 후 무기하 기법하에 30 도 내시경을 이용하여 기관 분기부 상방 기관 전벽에 위치하는 육아조직을 확인하였다(Fig. 3). 육아조직은 기관 전벽에 종축 으로 약 $2 \mathrm{~cm}$ 길이로 위치하고 있었으며 KTP 레이저(power $5 \mathrm{~W}$, continuous mode; Quanta System)를 육아종 근처에 위 치시킨 후 직접 조사하는 방법으로 제거하였다(Fig. 3). 산소 포화도를 확인해가며 필요 시 기관 캐뉼라 삽관 및 산소 공급 을 해주며 진행하였고 수술에 소요된 시간은 약 10 분가량이 었다. 레이저로 병변을 제거한 후 내시경으로 잔여 육아종이 없음을 확인한 후 기관 캐뉼라를 재삽입하고 수술을 종료하 였다. 수술 후 7 개월 째 호흡곤란이나 천명음 등의 증상은 없 으며 후두내시경 검사에서 육아종 재발 소견은 없는 상태로

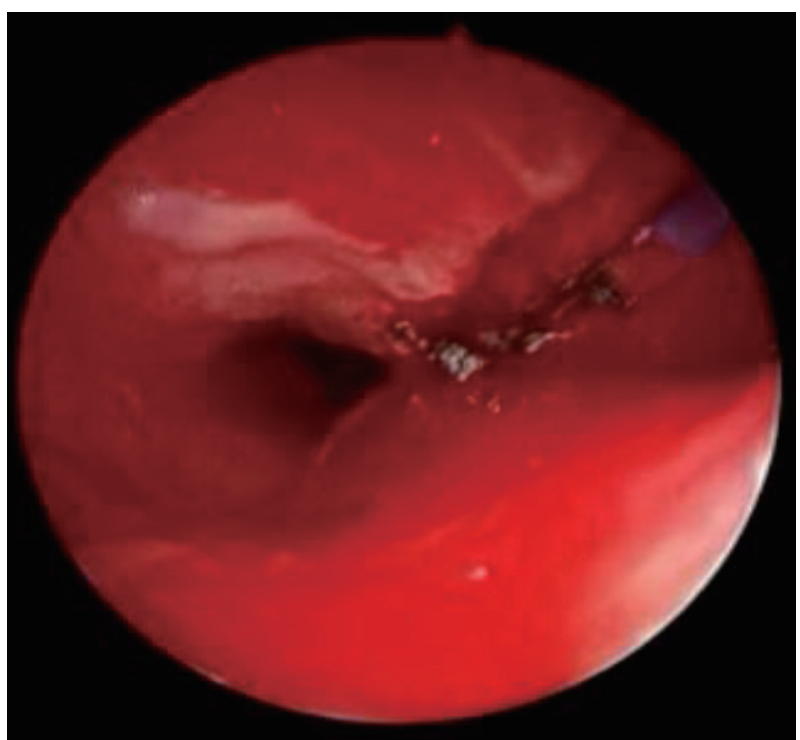

Fig. 2. Electrocauterization was performed due to bleeding occurred during granuloma removal with Bovie at first operation. 


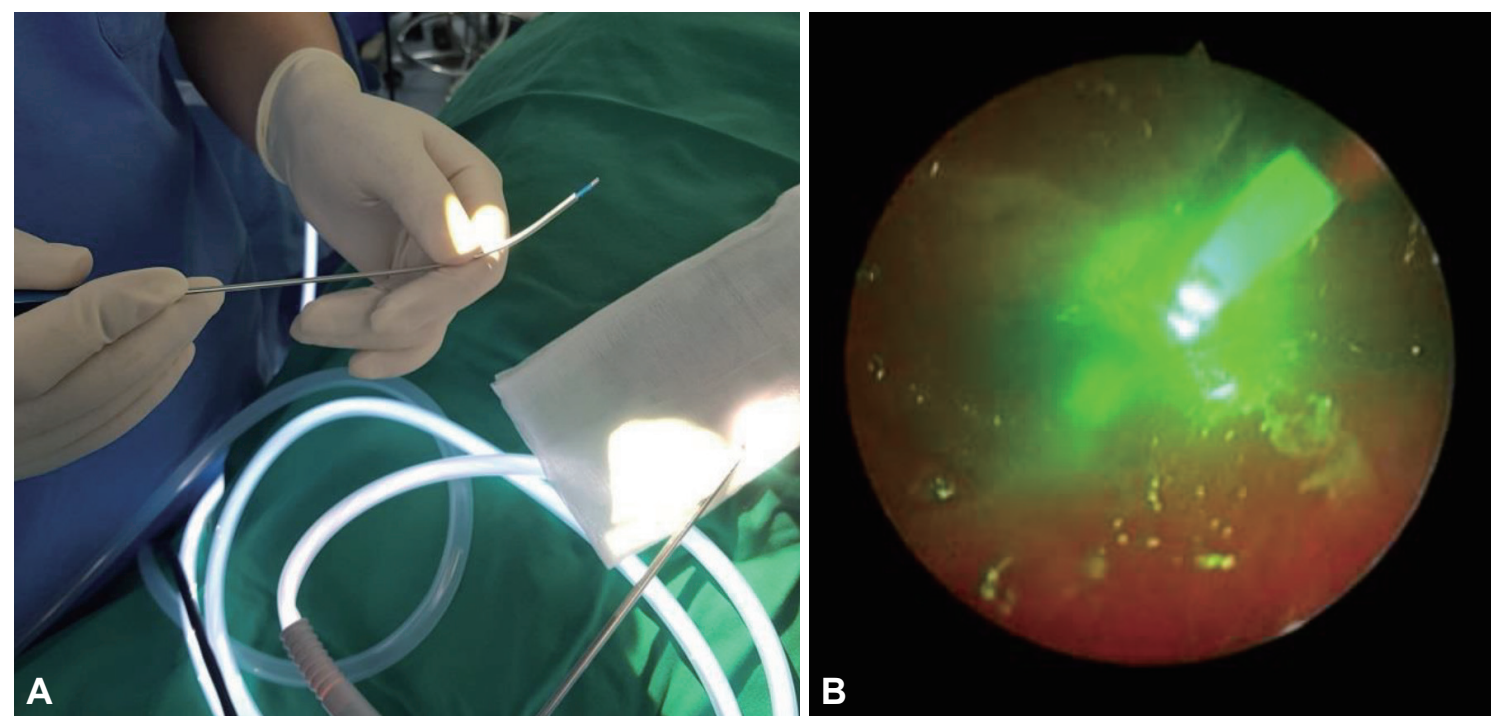

Fig. 3. Tracheal granuloma removal using KTP laser. A: Handpiece with flexible wire. B: Wire tip operated by KTP laser. KTP: potassium-titanyl-phosphate.

경과 관찰 중에 있다(Fig. 4).

\section{고 찰}

소아에서 기관절개술 후 합병증의 발생은 술 후 1 주일을 기 준으로 초기 합병증과 후기 합병증으로 구분하는데, 합병증 의 양상이 이 시점 전후로 다르기 때문이다. ${ }^{1)}$ 기관절개 후 합 병증 발생률에 대해 우리나라의 환아를 대상으로 한 연구에 서 Chung 등 $)^{5}$ 은 $1.4 \%$ 의 초기 합병증, $38.5 \%$ 의 후기 합병증 을 보고하였으며, $\operatorname{Kim}$ 등 1,6 은 $7.4 \%$ 의 초기 합병증, $44.6 \%$ 의 후기 합병증을 보고하였다. 초기 합병증으로는 예기치 않은 발 거, 튜브 폐색, 감염, 피하기종, 폐기종, 출혈 등이 보고되었고 후 기 합병증은 폐렴, 기관식도루, 기관협착 등이 보고되었다.5,56

이 중 기관절개술 후 발생하는 협착의 많은 원인은 대부분 기관 내 튜브로 인한 손상으로 발생하는 육아종인 것으로 보고되고 있으며,") $\mathrm{Kim}$ 등1,6은 육아조직 발생에 관여하는 여 러 요소들 중 기관절개의 기간이 3 개월 이상일 경우 합병증 의 발생이 유의하게 증가하였음을 보고하였다. 또한, 신경계 질환을 않고 있는 경우 타액, 위산 등이 후두의 방어 작용 없 이 기도 내로 흡인되어 육아조직 형성의 빈도를 증가시키는 것을 보고하였고 그것에 더하여 호흡기 감염이 동반된 경우 세균에 오염된 객담에 의해 영향을 받아 육아조직 발생이 증 가하는 것을 보고하였다. ${ }^{1)}$ 이렇게 발생한 기관 내 육아조직 으로 인해 기관 폐색이 발생한 환자는 부위와 크기에 따라 호흡곤란이 발생하며 경우에 따라 생명이 위험할 수 있다.

기관 내 육아종을 치료하기 위한 내시경적 방법은 레이저를 이용한 종물 절제, 풍선 확장술, 스텐트 거치법 등이 있다. 내

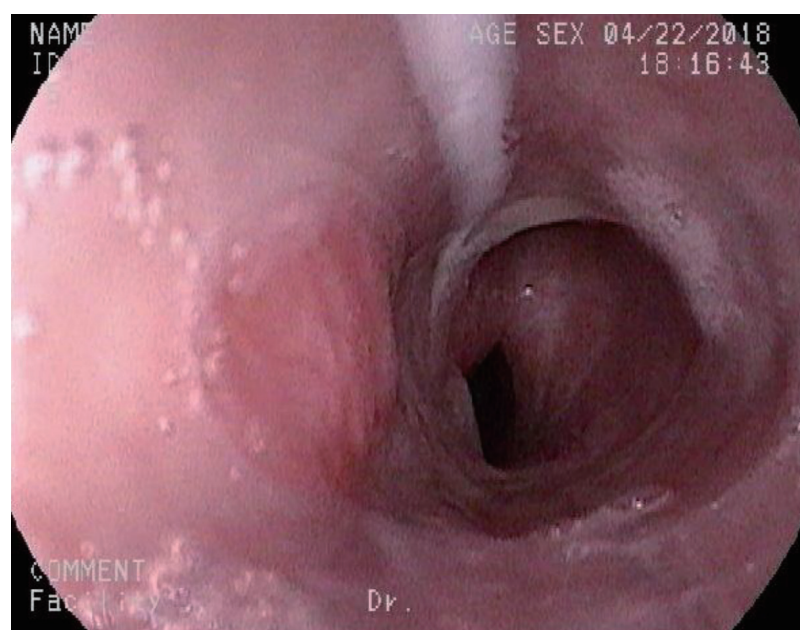

Fig. 4. Seven months after laser surgery, laryngoscopic imaging shows recovered tracheal mucosa.

시경하 육아종 절제법에 적용되는 레이저는 $\mathrm{CO}_{2}, \mathrm{Nd}: \mathrm{Yag}$, $\mathrm{KTP}$ 가 있으며, 그 중 $\mathrm{CO}_{2}$ 레이저는 수분을 강하게 흡수하고 상피 표면을 기화시켜 병변을 파괴하여 병변과 그 주변 조직 에 열 손상을 가할 가능성과 이로 인한 술 후 반흔을 형성할 가능성이 있으며, 에너지가 직선형으로 병변에 도달되기 때문 에 기관 내 다양한 병변에 적용하는 데 한계점이 있다. ${ }^{2)}$

본 증례에서 사용한 KTP 레이저는 녹색 빛을 발산하는 532 $\mathrm{nm}$ 파장을 가진 레이저로, $532 \mathrm{~nm}$ 파장은 헤모글로빈에 잘 흡수되어 미세혈관의 광지혈작용(photocoagulation)을 통해 높은 지혈 효과를 지니며, 에너지가 병변에 국한되는 특징이 있 어 주변 정상 조직에 대한 손상을 최소화하면서 종물을 제거 할 수 있음을 인정받아 최근 다양한 후두 양성 질환에 적용 되고 있다.8,9) 또한 KTP 레이저는 유연한 광섬유 전달시스템 
을 통해 쉽게 전달되며 다른 레이저보다 흡입 카테터 및 경직 형 기관지내시경 등을 통해 에너지가 병변에 보다 정확하게 전 달될 수 있다는 장점이 있다. 이러한 구조적 특징은 기관 캐뉼 라로 인해 기관 내강 내 다양한 부위에 발생하는 내 육아조직 접근 및 제거에 특히 유용하며 비교적 경미한 기관 내 협착의 경우에서 추가적인 시술 없이 KTP 레이저를 이용하여 치료가 가능하도록 한다. ${ }^{9}$

본 증례의 환아 또한 KTP 레이저를 이용하여 술 중 출혈 등으로 인한 특별한 합병증 발생 없이 수술 시야를 충분히 확 보하면서 안전하게 기관 내 육아조직을 모두 제거할 수 있었 으며, 추적 기간 동안 호흡곤란이나 천명음 등의 증상과 기관 내 육아종 재발 소견은 보이지 않았다. 향후 KTP 레이저의 효용성을 확인하기 위해 더 많은 치료 경험을 토대로 한 비교 분석이 필요하겠지만 저자들은 본 증례를 통해 KTP 레이저 를 통한 기관 내 육아종 제거는 침습적 술기 없이 안전하게 종 물의 섬세한 절제가 가능하다는 것을 보여 주었으며 기관 내 발생한 육아종 치료에 효과적인 대안이 될 수 있을 것으로 사 료된다.

중심 단어: 기관, 육아종, KTP 레이저.

Acknowledgments

None.

Conflicts of Interest

The authors have no financial conflicts of interest.
Authors' Contribution

Conceptualization: GilJoon Lee. Supervision: GilJoon Lee. Visualization: all authors. Writing_original draft: all authors. Writingreview \& editing: all authors. Approval of final manuscript: all authors.

\section{REFERENCES}

1. Kim KH, Sung MW, Oh SJ, Jeong HS, Choi BY, Park MH, et al. Complications in pediatric tracheotomy. Korean J Otolaryngol 2000;43 (12):1350-4.

2. Ho AS, Koltai PJ. Pediatric tracheal stenosis. Otolaryngol Clin North Am 2008;41(5):999-1021.

3. Gaudet PT, Peerless A, Sasaki CT, Kirchner JA. Pediatric tracheostomy and associated complications. Laryngoscope 1978;88(10):1633-41.

4. Mandell DL, Yellon RF. Endoscopic KTP laser excision of severe tracheotomy-associated suprastomal collapse. Int J Pediatr Otorhinolaryngol 2004;68(11):1423-8.

5. Chung MH, Kim SH, Jang MS, Lee JH, Han JW, Lee JH. A clinical study of tracheotomy in pediatrics. Korean J Otolaryngol 1998;41(11): 1472-7.

6. Kim CH, Lee JW, Oh JH, Choung YH, Park MS. A clinical study of pediatric tracheotomy. Korean J Otolaryngol 2005;48(4):500-5.

7. Law JH, Barnhart K, Rowlett W, de la Rocha O, Lowenberg S. Increased frequency of obstructive airway abnormalities with longterm tracheostomy. Chest 1993;104(1):136-8.

8. Rutter MJ, Cohen AP, de Alarcon A. Endoscopic airway management in children. Curr Opin Otolaryngol Head Neck Surg 2008;16(6): 525-9.

9. Ishman SL, Kerschner JE, Rudolph CD. The KTP laser: an emerging tool in pediatric otolaryngology. Int J Pediatr Otorhinolaryngol 2006; 70(4):677-82. 